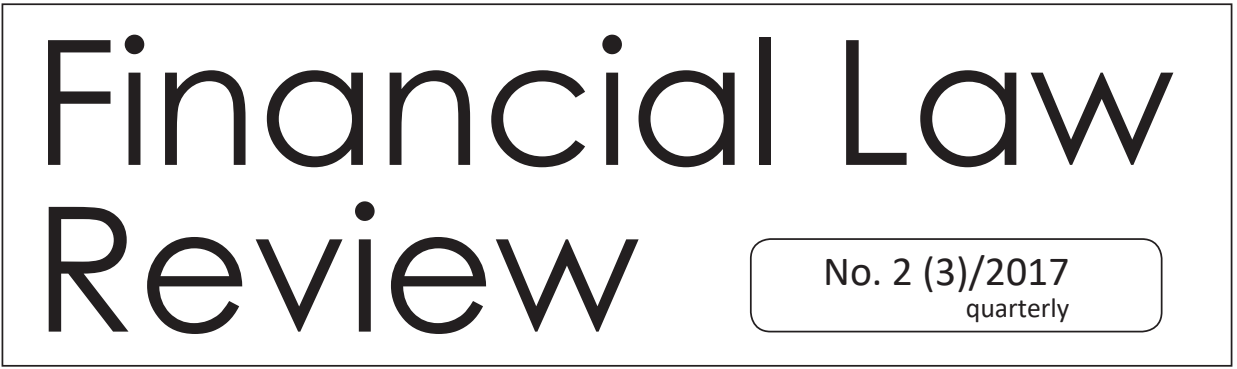

UNIVERSITY OF GDAŃSK • FACULTY OF LAW AND ADMINISTRATION http://www.ejournals.eu • http://czasopisma.bg.ug.edu.pl

\title{
PODSTAWOWE SZPITALNE ZABEZPIECZENIE ŚWIADCZEŃ OPIEKI ZDROWOTNEJ W SYSTEMOWYM KONTEKŚCIE FINANSOWANIA OCHRONY ZDROWIA ZE ŚRODKÓW PUBLICZNYCH
}

Szymon Mos

\section{Streszczenie}

Artykuł zawiera rozważania w zakresie ostatnich zmian legislacyjnych w finansowaniu obszaru leczenia szpitalnego, wprowadzających system podstawowego szpitalnego zabezpieczenia świadczeń opieki zdrowotnej (tzw. sieć szpitali); zmiany te, mimo ich systemowego umiejscowienia i oparcia na dotychczasowym otoczeniu regulacyjnym, kontrastują z obecnymi rozwiązaniami i stanowić mogą pierwszy etap zmiany modelu finansowania ochrony zdrowia ze środków publicznych.

\section{Słowa kluczowe}

Ochrona zdrowia, finansowanie ochrony zdrowia, ryczałt, sieć szpitali 


\section{Summary}

The article discusses recent changes in financing hospital treatment in Poland, which introduced so-called "hospital network”. Despite being placed in and leaning on an already-existing regulatory environment, the network contrasts with the current system solutions and might in fact be a first step to changing the model of financing healthcare in Poland from the public funds.

\section{Key words}

Healthcare, financing of health care, a lump sum, hospital network

Punktem wyjścia do analizy polskiego systemu ochrony zdrowia, poprzez pryzmat prawa do ochrony zdrowia, czy też bardziej szczegółowo w aspekcie jego finansowania, jest Konstytucja RP ${ }^{1}$. Pozostając w korelacji z aktami międzynarodowymi², w znacznym zakresie implementowanymi do naszego porządku prawnego w związku z akcesją do Unii Europejskiej, zawiera ona podstawowe normy stanowiące wskazania dla ustawodawcy w kształtowaniu całości rozwiązań systemowych, od praw (i uprawnień) pacjenta, przez ustrój, organizację, finansowanie, aż po zasady wykonywania zawodów medycznych i szereg innych regulacji towarzyszących.

Najobszerniejszym pod względem treści normatywnej artykułem Konstytucji RP w omawianym zakresie jest art. 68.

Każdemu człowiekowi przepis ust. 1 tego artykułu przyznaje prawo do ochrony zdrowia. Na kogo zatem rozciąga się moc Konstytucji RP, ten uprawniony jest w oparciu o nią do ochrony zdrowia; nakazane jest jednocześnie, by jego zdrowie chronić. To uniwersalne prawo człowieka3

Konkretyzuje i zawęża z kolei przepis ust. 2 przytoczonego artykułu zakresowo tak podmiot, jak i przedmiot regulacji. Nakłada bowiem na władzę publiczną

\footnotetext{
${ }^{1}$ Konstytucja Rzeczypospolitej Polskiej z dnia 2 kwietnia 1997 r. (Dz. U. Nr 78, poz. 483 z późn. $\mathrm{zm}$.).

2 Prawo do ochrony zdrowia, jako prawo drugiej generacji, jest prawem człowieka i prawem podstawowym. Zakotwiczone w Powszechnej Deklaracji Praw Człowieka i Obywatela ONZ z 10 grudnia 1948 r. (art. 25) znajduje swoją kontynuację w Międzynarodowym Pakcie Praw Gospodarczych, Społecznych i Kulturalnych (art. 12) i jako sygnatariusz tego paktu jest nimi związana także Rzeczypospolita Polska. Szeroki wachlarz regulacji zawiera się także w aktach prawnych organów Unii Europejskiej - Dyrektywach, rozporządzeniach i orzeczeniach sądów Unii Europejskiej, na czele z TSUE.

${ }_{3}$ M. Dercz, Prawo do ochrony zdrowia w świetle przepisów Konstytucji RP [w:] M. Dercz (red.), Prawo publiczne ochrony zdrowia, Warszawa 2013, s.42.
} 
obowiązek: po pierwsze niejako zorganizowania na rzecz obywateli opieki zdrowotnej finansowanej ze środków publicznych, po drugie zaś wyznacza równolegle, że bez względu na sytuację materialną tych uprawnionych obywateli, dostęp ten ma być równy. Choć szczegółowe rozwiązania pozostawione są do dookreślenia w drodze ustawy, to warto zauważyć, że owa równość z jednej strony wyrażać się może poprzez zapewnienie całkowicie nieodpłatnego dostępu do świadczeń zdrowotnych dla obywatela polskiego, ale także przez zapewnienie równej odpłatności ${ }^{4}$ dla wszystkich obywateli, przy jednoczesnym wprost sformułowanym zakazie dyskryminacji z uwagi na status majątkowy uprawnionego. Konsekwencją tej zasady jest także obowiązek władzy publicznej zapewnienia takiego otoczenia regulacyjnego, w którym świadczeniodawcy będą obowiązani do poszanowania zasady równego dostępu ${ }^{5}$. Omawiana w niniejszym artykule zmiana w finansowaniu ze środków publicznych obszaru leczenia szpitalnego wpisuje się wykonawczo tym właśnie ustępem w statuowany obowiązek.

Pozostałe przepisy wskazanego artykułu Konstytucji, kładąc obowiązki na władze publiczne, wprowadzają ochronę szczególną dla określonych grup społecznych (kobiety, dzieci, osoby niepełnosprawne, osoby starsze), a także odnoszą się do zagadnień szeroko rozumianego zdrowia publicznego z elementami ochrony środowiska ${ }^{6}$.

W tym miejscu poczynić należy uwagę natury ogólnej, że oczywiście środki finansujące całość szeroko rozumianego sektora ochrony zdrowia pochodzić mogą zarówno ze źródeł publicznych jak i innych, niepublicznych (a zatem źródeł prywatnych, to znaczy funkcjonujących poza sferą imperium państwa) ${ }^{7}$. W zakresie rozważanego niniejszym artykułem obszaru szczególnie jawi się pytanie o pojemność terminu: „źródła publiczne finansowania sektora ochrony zdrowia”.

\footnotetext{
4 Można zakładać, że mowa tu zarówno o współpłaceniu jak i nawet ubezpieczeniach dodatkowych czy prywatnych. Szerzej zob. E. Nojszewska (red.), System ochrony zdrowia. Problemy i możliwości ich rozwiązań, Warszawa 2011.

${ }^{5}$ M. Dercz, op. cit., [w:] M. Dercz (red.), Prawo..., s. 43.

${ }^{6}$ Oczywiście nie tylko normy art. 68 Konstytucji RP wpływają na kształt ochrony zdrowia jako systemu czy też ogólnie rozumianego zbioru norm prawnych regulujących całokształt tej sfery. Wskazać można chociażby sztandarowy art. 38 statuujący fundamentalną ochronę poprzez prawo każdego człowieka do życia. Szerzej zob.: Agnieszka J. Kowalska-Olczyk, Pacjent jako podmiot mający prawo do świadczeń zdrowotnych [w:] J. Pacian (red.), Prawna ochrona zdrowia pacjenta, Warszawa 2017, s. 81-84. W zakresie niniejszego artykułu, przy świadomości ich istnienia i funkcjonowanie, odwoływanie się do wszystkich możliwych norm konstytucyjnych jest niecelowe.

7 P. Białynicki-Birula, Zmiany w systemie finansowania ochrony zdrowia w Polsce. Perspektywa międzynarodowa, Kraków 2006, s. 75
} 
Przyjmuje się zatem, że to kwalifikacja przez ustawodawstwo danych środków do środków publicznych decyduje o tym, czy możemy mówić o danym źródle finansowania jako o źródle publicznym, bez względu na to, kto środkami tymi dysponuje w obszarze zarządczym - może być to zarówno organ administracji publicznej jak i inny podmiot zarządzający. W samych zaś źródłach publicznych szczególnego dostrzeżenia domagają się budżety państw i budżety jednostek samorządu terytorialnego, w zakresie tych pierwszych z uwzględnieniem także źródeł takich jak fundusze celowe, adresujące swoim wsparciem określone dziedziny ochrony zdrowia (np. rehabilitację osób niepełnosprawnych) i różnego rodzaju fundusze zdrowotne pod zarządem powszechnych instytucji ubezpieczeniowych, które opierają stronę przychodową na składce zdrowotnej (ubezpieczeniowej) ${ }^{8}$.

System najbardziej zbliżony do składkowego obowiązuje w Rzeczypospolitej Polskiej (nie jest to oczywiście system modelowy i ma szereg cech mieszanych, przeważają jednakże rozwiązania systemu składkowego). Należy zwrócić uwagę, że wciąż, kierując się wytycznymi konstytucyjnymi, to do ustawodawcy należy określenie sposobu dystrybucji środków w systemie ochrony zdrowia. Wyodrębnienie przez ustawodawcę w Konstytucji RP środków publicznych jako źródła finansowania opieki zdrowotnej dla obywateli w logiczny sposób implikuje umiejscowienie Narodowego Funduszu Zdrowia (NFZ) - płatnika systemu (o płatniku szerzej w dalszej części artykułu) - w art. 9 pkt. 9 ustawy z dnia 27 sierpnia 2009 r. o finansach publicznych ${ }^{9}$ (uofp) jako podmiot tworzący sektor finansów publicznych; na tym o co do zasady kończy się zakres bezpośredniego, zindywidualizownego „zainteresowania” uofp Funduszem.

Ustawą, która niejako wypełnia wspomniane nakazy, wyrażone w art. 68 ust. 2 Konstytucji RP jest ustawa z dnia 27 sierpnia 2004 r. o świadczeniach opieki zdrowotnej finansowanych ze środków publicznych ${ }^{10}$ (uśoz). Pozostaje ona oczywiście jednym $\mathrm{z}$ wielu aktów prawnych regulujących sferę ochrony zdrowia „wypełniających” ramy konstytucyjne ${ }^{11}$.

\footnotetext{
${ }^{8}$ Ibidem, s. 75-76. Odnośnie roli samorządu terytorialnego trafnie zauważa autor, że o ile rola budżetów państwa wynika $\mathrm{z}$ interwencji tegoż państwa $\mathrm{w}$ ochronę zdrowia, o tyle aktywność samorządu terytorialnego wiązać należy przede wszystkim z jego rolą jako organu założycielskiego jednostek opieki zdrowotnej, a środki pieniężne pochodzące z samorządu mają charakter uzupełniający.

9 Ustawa z dnia 27 sierpnia 2009 r. o finansach publicznych t.j. Dz. U. z 2017 r. poz. 2077.

10 Ustawa z dnia 27 sierpnia 2004 r. o świadczeniach opieki zdrowotnej finansowanych ze środków publicznych (t.j. Dz. U. z 2017 r. poz. 1938).

11 „Ilość" materiału normatywnego w obszarze ochrony zdrowia dobrze obrazuje na przykład próba sporządzenia wykazu aktów prawnych stanowiących tą dziedzinę prawa, zob. A. Fiutak, Prawo $w$ medycynie, Warszawa 2010, s. 6-11.
} 
Uchwalona $\mathrm{w}$ realiach reformy zmieniającej wcześniej funkcjonujący system kas chorych poprzez ich likwidację i wprowadzenie scentralizowanego płatnika w postaci Narodowego Funduszu Zdrowia ${ }^{12}$, stanowiła odpowiedź na orzeczenie Trybunału Konstytucyjnego ${ }^{13}$ stwierdzającego w szerokim zakresie niekonstytucyjność przepisów ustawy z dnia 23 stycznia 2003 r. o powszechnym ubezpieczeniu w Narodowym Funduszu Zdrowia ${ }^{14}$. Definiuje uśoz pośrednio pojęcie opieki zdrowotnej, w sposób szczególny, poprzez wyodrębnienie świadczeń zdrowotnych, świadczeń zdrowotnych rzeczowych i świadczeń towarzyszących, określenie celu tych świadczeń oraz zakreślenie świadczeń gwarantowanych przysługujących świadczeniobiorcom ${ }^{15}$. Przypisuje także konkretne role regulacyjne (zwłaszcza $\mathrm{w}$ drodze delegacji ustawowych do wydawania przez ministra właściwego do spraw zdrowia rozporządzeń), organizacyjne i płatnicze w ochronie zdrowia ${ }^{16}$.

Wspomniany już Narodowy Fundusz Zdrowia to państwowa jednostka organizacyjna posiadająca osobowość prawną, będąca państwowym funduszem celowym; $\mathrm{w}$ świetle przepisów uśoz pełni przede wszystkim rolę płatnika ${ }^{17}$ jako jednostka sektora finansów publicznych, co wynika z przytaczanych wyżej przepisów uofp. A zatem, w wykonaniu obowiązków nałożonych poprzez przepis art. 68 ust. 2 Konstytucji RP na władzę publiczną, gromadzi środki przeznaczone na ochronę zdrowia i zapewnia ich wydatkowanie zapewniając równy dostęp uprawnionym świadczeniobiorcom bez względu na ich sytuację materialną. Zasadniczo NFZ jest zobligowany do aktywności w tym zakresie, zdeterminowanej wyżej wspomnianymi przesłankami i ma bezwzględny obowiązek finansowania świadczeń wskazanych $\mathrm{w}$ uśoz ${ }^{18}$. Fundusz działa, zgodnie z przepisem art. 98 ust. 7 uśoz na podstawie ustawy i statutu ${ }^{19}$, nadawanego w zw. z przepisem art. 98 ust. 8 przez ministra właściwego do spraw zdrowia.

\footnotetext{
12 Szerzej zob.: E. Nojszewska, Uwarunkowania prawne i ekonomiczne możliwości komercyjnego świadczenia usług medycznych przez polskie szpitale publiczne (SPZOZ) na tle ekonomii finansowania ochrony zdrowia, [w:] E. Nojszewska, W. Malinowski, S. Sikorski, Komercyjne świadczenie ustug medycznych przez szpitale. publiczne, Warszawa 2017, s. 28-39.

${ }_{13}$ Wyrok Trybunału Konstytucyjnego z dnia 7 stycznia 2004 r., sygn. K 14/03, Dz. U. Nr 5, poz. 37.

14 Dz. U. z 2003 r., Nr 45, poz. 391 z późn. zm.

${ }_{15}$ H. Izdebski, Rozdział wstępny. Uwagi wprowadzające, podstawowe kwestie, podstawowa terminologia [w:], M. Dercz (red.), Prawo..., s. 29-30.

16 M. Dercz, op. cit. [w:] M. Dercz (red.), Prawo..., s. 60-65.

${ }^{17}$ Choć role głównych aktorów systemu przeplatają się; tak np. w określonym zakresie NFZ pełni także zadania regulacyjne, zaś odnośnie pewnych obszarów płatnikiem jest minister właściwy do spraw zdrowia.

18 Ibidem, s. 63-64.

19 Rozporządzenie Ministra Zdrowia z dnia 11 grudnia 2014 r. w sprawie nadania statutu Narodowemu Funduszowi Zdrowia. (Dz. U. poz. 1840).
} 
Podkreślenia w tym miejscu wymaga, że o ile płatnik wpisuje się w otoczenie regulacyjne, pozostające w pierwszej kolejności uprawnieniem władzy ustawodaw$\mathrm{czej}^{20}$ (ewentualnie udzielającej delegacji ustawowej podmiotom uprawnionym lub kształtującej pewne swoiste rozwiązania w obszarze płatnika), o tyle ta właśnie władza ustawodawcza realizując dyspozycje przepisu art. 68 ust. 2 Konstytucji ma za zadanie takie normatywne ukształtowanie systemu, które zapewni holistyczną realizację uprawnień konstytucyjnych, a więc także zapewni funkcjonowanie odpowiedniej sieci placówek (świadczeniodawców) - nie będąc przecież ich organem założycielskim - realizujących zadania z zakresu opieki zdrowotnej ${ }^{21}$.

Mając na uwadze, że to właśnie w uśoz ustawodawca realizuje zadania nałożone na niego poprzez art. 68 ust. 2 Konstytucji, w tym zakreśla ramy i zasady funkcjonowania płatnika jakim jest Narodowy Fundusz Zdrowia, prima facie nie budzi wątpliwości, że zmian w obszarze zasad finansowania ochrony zdrowia wprowadzających system podstawowego szpitalnego zabezpieczenia opieki zdrowotnej dokonano właśnie poprzez nowelizację tej ustawy.

System podstawowego szpitalnego zabezpieczenia świadczeń opieki zdrowotnej $\left(\right.$ PSZ ${ }^{22}$ wprowadzony został do uśoz zasadniczo jako dział IVB przez ustawę nowelizującą z 23 marca 2017 r. ${ }^{23}$ (ustawa nowelizująca). Projekt, skierowany do Sejmu jako rządowy ${ }^{24}$, prowadzony był na etapie prac w rządzie przez Ministra Zdrowia ${ }^{25}$.

Uzasadnienie projektu ministerialnego wskazuje, że zadaniem ustawy jest wprowadzenie nowej instytucji prawnej, która w pierwszym rzędzie zaadresuje dwa aspekty finansowania ze środków publicznych opieki specjalistycznej, jaką w szczególności jest leczenie szpitalnie, mianowicie kwestię należytego poziomu finansowania realizowanych $\mathrm{w}$ placówkach szpitalnych świadczeń oraz zagwarantowanie placówkom tym ciągłości i stabilności finansowania jako

${ }^{20}$ Oczywiście w ustrojowych ramach procesu legislacyjnego, a więc mając na uwadze pełen zakres podmiotów uprawnionych do inicjatywy ustawodawczej; jednakże nadanie ostatecznego kształtu proponowanym rozwiązaniom przynależy zawsze izbom parlamentu.

${ }_{21}$ A. Wołoszyn, G. Lubeńczuk, Normatywne uwarunkowania reformy systemu ochrony zdrowia, [w:] E. Nojszewska (red.), System ochrony zdrowia. Problemy i możliwości ich rozwiązań, Warszawa 2011, s. 574

${ }^{22}$ Potocznie zwany przez samego projektodawcę „siecią szpitali”.

${ }^{23}$ Ustawa z dnia 23 marca 2017 r. o zmianie ustawy o świadczeniach opieki zdrowotnej finansowanych ze środków publicznych. (Dz. U. poz. 844).

${ }^{24}$ Druk Sejmowy $\mathrm{Nr}$ 1322, http://orka.sejm.gov.pl/Druki8ka.nsf/0/97F9FDA8C82AE93FC12580D10031F4D2/\%24File/1322.pdf, dostęp: 15.10.2017 r.

${ }^{25}$ Projekt z dnia 26.09.2017 wraz z uzasadnieniem i oceną skutków regulacji https://legislacja.rcl. gov.pl/docs//2/12290303/12380817/12380818/dokument246827.pdf, dostęp: 15.10.2017 r. 
istotnych, w postrzeganiu ustawodawcy, dla zabezpieczenia dostępu do świadczeń zdrowotnych ${ }^{26}$.

Dla czytelności rozważań omówienia, choćby w zarysie, wymaga system, funkcjonujący w tym obszarze świadczeń przed uchwaleniem ustawy nowelizującej.

Przede wszystkim zaznaczyć trzeba, że w sposób jednoznaczny udzielanie świadczeń zdrowotnych finansowanych ze środków publicznych opierać się może jedynie o zawartą pomiędzy świadczeniodawcą a Narodowym Funduszem Zdrowia umowę cywilnoprawną, w praktyce zwaną kontraktem. Przepisy działu VI uśoz „Postępowanie w sprawie zawarcia umów ze świadczeniodawcami” (w ust. 1 art. 132) nie pozostawiają co do tego żadnych wątpliwości, a wszelkie wyjątki z zasadą tą sprzeczne muszą znaleźć swoje umocowanie rangi ustawowej. Kreowany w ten sposób stosunek prawny jest jednym $\mathrm{z}$ trzech charakteryzujących całość systemu ubezpieczeniowego (pozostałe dwa to stosunek między ubezpieczonym a NFZ oraz między ubezpieczonym-uprawnionym do świadczeń a świadczeniodawcą ${ }^{27}$ ).

Sposób wyboru świadczeniodawcy regulowany jest właśnie w przepisach działu VI uśoz. Przewiduje on w istocie trzy tryby prowadzące do zawarcia umowy: konkurs ofert, rokowania i tryb potocznie nazywany trybem wnioskowym ${ }^{28}$.

Poprzez konkurs, ogłoszony zostaje względem nieograniczonej liczby adresatów, Narodowy Fundusz Zdrowia definiuje przedmiot zamówienia ${ }^{29}$, oraz inne okoliczności i wymagania i poprzez powołaną komisję konkursową dokonuje oceny złożonych ofert w części jawnej i niejawnej postępowania w oparciu o kryteria oceny określone na podstawie uśoz i przepisów wykonawczych. Obecnie postępowanie konkursowe cechuje się znacznym stopniem „automatyzmu” poprzez wysoki stopień udziału instrumentów elektronicznych ${ }^{30}$. Dokonanie wyboru ofert najkorzystniejszych (lub żadnej z ofert, jeśli nie dają możliwości

\footnotetext{
${ }^{26}$ Ibidem, s. 8.

27 Szerzej zob. Agnieszka J. Kowalska-Olczyk, op. cit. [w:] J. Pacian (red.), Prawna ochrona..., s. $87-88$

${ }_{28}$ A. Pietraszewska-Macheta, Kontraktowanie świadczeń przez Narodowy Fundusz Zdrowia. Przepisy, praktyka i orzecznictwo, Warszawa 2014, s. 33.

${ }^{29}$ Nie należy jednakże utożsamiać NFZ z „Zamawiającym” w rozumieniu art. 2 pkt. 12 Ustawy z dnia 29 stycznia 2004 r. - Prawo zamówień publicznych. (t.j. Dz. U. z 2017 r. poz. 1579), a „przedmiotu zamówienia" rozumieć w znaczeniu w tejże ustawie używanym, bowiem norma art. 138 uśoz wprost wyłącza stosowanie ustawy Prawo zamówień publicznych do zawierania umów o udzielanie świadczeń opieki zdrowotnej.

${ }^{30}$ Ibidem, s. 34.
} 
właściwego udzielania świadczenn ${ }^{31}$ ) może mieć miejsce w części jawnej albo, fakultatywnie wedle wyboru komisji konkursowej, niejawnej, w której prowadzone są jeszcze z oferentami negocjacje celem określenia ilości planowanych do udzielenia świadczeń i ich ceny.

Również rokowania prowadzi się w trybie jawnym i niejawnym. Mają one miejsce w sytuacjach ściśle przez ustawę określonych, do których należą unieważnienie postępowania konkursowego (przy zachowaniu tych samych co w konkursie wymagań), pilna, niemożliwa do przewidzenia konieczność zawarcia umowy o udzielanie świadczeń opieki zdrowotnej, ograniczona, nie większa niż pięciu liczba świadczeniodawców gotowych udzielać świadczeń będących przedmiotem postępowania (art. 144 pkt. 1-3 uśoz). Prowadzi się je też na skutek uwzględnienia przez właściwy organ odwołania świadczeniodawcy, to jest w tym wypadku przez dyrektora oddziału wojewódzkiego Narodowego Funduszu Zdrowia.

Podmioty są do rokowań zapraszane, co nie oznacza jednak pełnej dowolności. Regulują to ściśle przepisy ustawy.

W trybie wnioskowym zaś to świadczeniodawca spełniający określone przepisami warunki ubiega się o zawarcie umowy z płatnikiem. Takie rozwiązania znajdują zastosowanie przy organizacji podstawowej opieki zdrowotnej (POZ) czy zaopatrzeniu w wyroby medyczne ${ }^{32}$. Jako nieistotne dla niniejszych wywodów, pozostawić je należy na marginesie rozważań.

Rozliczanie świadczeń w systemie kontraktowym - uogólniając - uzależnione jest zatem, w trybie konkursu ofert i pokrewnym mu systemie rokowań, od rozliczania na podstawie zawartych umów cywilnoprawnych ilości wykonanych świadczeń przemnożonych przez stawkę określoną za dane świadczenie. Iloczyn stanowi podstawę do ubiegania się, przy spełnieniu całego szeregu warunków szczegółowych i w zgodzie z procedurami, przez świadczeniodawcę o dokonanie przez płatnika zapłaty na jego rzecz za wykonane świadczenia, w ramach limitu finansowego co do zasady ustalanego przez NFZ na poszczególne rodzaje świadczeń33.

\footnotetext{
${ }^{31} \mathrm{Na}$ etapie wstępnym oferty mogą także podlegać odrzuceniu z powodów, o których mowa w ustawie. Spośród nich warto zwrócić uwagę na te, które zdają się być szczególnie nakierowane na wytworzenie mechanizmu ochrony środków publicznych jakimi dysponuje płatnik, jak np. art. 149 ust. 1 pkt 88 statuujący, że odrzuceniu podlega oferta złożona przez świadczeniodawcę, z którym w okresie 5 lat poprzedzających ogłoszenie postępowania, została rozwiązana przez wojewódzki oddział NFZ umowa o udzielanie świadczeń odpowiadającym przedmiotowi ogłoszenia, bez zachowania okresu wypowiedzenia z przyczyn leżących właśnie po stronie świadczeniodawcy

32 Szerzej zob.: ibidem s. 88-94.

${ }^{33} \mathrm{Z}$ zastrzeżeniem oczywiście funkcjonowania w systemie tzw. nadwykonań i świadczeń nielimitowanych, co pozostaje na marginesie rozważań niniejszego artykułu.
} 
Do wspomnianych wyżej przepisów wykonawczych, dających podstawę, poza normami ustawowymi czy też trafniej: poszerzającymi te normy w wyniku delegacji ustawowej, do przeprowadzenia postępowań należy zaliczyć nie tylko rozporządzenia ministra właściwego do spraw zdrowia, ale także szereg zarządzeń Prezesa Narodowego Funduszu jak i dyrektorów oddziałów wojewódzkich.

Jak już nadmieniono przewidziano tryb odwoławczy. Art. 154 ust. 3 i 6 uśoz poprzez przyznanie prawa dyrektorowi wojewódzkiego oddziału NFZ do odwołania w drodze decyzji administracyjnej precyzyjnie kreśli granicę, z którą zastosowanie znajdują przepisy prawa administracyjnego w stosunku do objętej interesem prawnym odwołującego sprawy: ustawy z dnia 14 czerwca 1960 r. Kodeks postępowania administracyjnego ${ }^{34}$ na etapie wnioskowania o ponowne rozpatrzenie sprawy przez dyrektora oddziału wojewódzkiego NFZ i ustawy z dnia 30 sierpnia 2002 r. Prawo o postępowaniu przed sądami administracyjnymi ${ }^{35}$ na etapie po otrzymaniu decyzji w wyniku tegoż ponownego rozpatrzenia.

Ustawa nowelizująca nie zmienia dotychczasowych trybów, dokonując jednocześnie wyodrębnienia podmiotowego w ten sposób, że w zakresie leczenia szpitalnego tryb konkursu ofert i rokowań pozostaje trybem subsydiarnym w stosunku do PSZ ${ }^{36}$. Jest to zatem w praktyce zmiana o bardzo szerokim oddziaływaniu, bowiem dotycząca jednego $\mathrm{z}$ najbardziej kosztochłonnych segmentów systemu ${ }^{37}$.

W uzasadnieniu do przedłożenia rządowego założono, że planowany podział środków pomiędzy PSZ a tryb konkursu ofert wynosić ma (w procentach) 85 do 15. Przeprowadzanie konkursów ofert ma za zadanie jednie uzupełnienie tych świadczeń zdrowotnych, w zakresie których na terenie danego województwa nie będą one należycie zaspokojone. Kompetencje do dokonania takiej oceny pozostawiono dyrektorowi wojewódzkiego oddziału $\mathrm{NFZ}^{38}$.

W ramach PSZ wprowadzono poziomy zabezpieczenia szpitali: I, II, III stopnia, onkologicznych lub pulmonologicznych, pediatrycznych, ogólnopolskich. Są one wyznaczane w zależności od rodzajów udzielanych świadczeń zdrowotnych, tzw. profili systemów zabezpieczenia, które precyzyjnie zdefiniowane są w art. 951

\footnotetext{
34 t.j. Dz. U. z 2017 r. poz. 1257.

35 t.j. Dz. U. z 2017 r. poz. 1369 z późn. zm.

36 Por. Druk Sejmowy Nr 1322, s. 22.

37 J. Leowski, Polityka zdrowotna a zdrowie publiczne. Ochrona zdrowia w gospodarce rynkowej, Warszawa 2004, s. 98.

38 Por. Druk Sejmowy Nr 1322, s. 22.
} 
ust. 3. Ustawodawca wymienia te profile katalogiem zamkniętym w art. 95l. ust. 4 pkt. 1-6. Klasyfikacja świadczeniodawcy do systemu zabezpieczenia opiera się o warunki brzegowe określone art. 95m, zawierające poza wskazanymi już profilami systemów zabezpieczenia także inne warunki, w tym wyjątki od ogólnie przyjętych reguł, umożliwiające np. kwalifikowanie danego podmiotu do określonego poziomu systemu zabezpieczenia, mimo nie spełniania przez ten podmiot wszystkich wymaganych profili systemu zabezpieczenia w sytuacji, gdy jest to uzasadnione koniecznością zapewnienia odpowiedniego dostępu do świadczeń opieki zdrowotnej.

Co istotne, mimo dość szeroko wskazanych kryteriów kwalifikacyjnych, ustawodawca pozostawił poprzez delegację do wydania rozporządzenia ministrowi właściwemu do spraw zdrowia dalszą swobodę w określeniu szczegółowych kryteriów dla każdego z poziomów zabezpieczenia i pewnych innych okoliczności istotnych w procesie kategoryzacji (art. 95m ust. 12) nakazując temu ministrowi uwzględnienie przy wydawanym rozporządzeniu potrzeby odpowiedniego zapewnienia dostępu do świadczeń opieki zdrowotnej, a także zapewnienie ciągłości i kompleksowości udzielanych świadczeń opieki zdrowotnej.

Jak podano w uzasadnieniu projektu przekazanego do prac parlamentarnych, ustawodawca poczynił założenie, że w tych częściach, w jakich są one zakontraktowane w szpitalach należących do podstawowego szpitalnego zabezpieczenia świadczeń opieki zdrowotnej, do PSZ włączone będą także świadczenia wysokospecjalistyczne, rehabilitacja lecznicza, ambulatoryjna opieka specjalistyczna (AOS) realizowana w przychodniach przyszpitalnych, programy lekowe, chemioterapia, świadczenia nocnej i świątecznej opieki zdrowotnej ${ }^{39}$.

Przyjrzeć należy się w tym miejscu nowym zasadom, na jakich oparto finansowanie PSZ, jak już bowiem ustalono klasyczny tryb konkursu ofert czy wywodzące się z niej rokowania zostały jedynie formą subsydiarną. Ustawa nowelizująca dodała do uśoz art. 136c. Ustala on, w przepisie ust.1, że świadczenia opieki zdrowotnej finansowane na podstawie umowy o udzielanie świadczeń opieki zdrowotnej w ramach profili systemu zabezpieczenia, finansowane są w formie ryczałtu systemu zabezpieczenia. Ustawodawca pozostawia wprawdzie miejsce na takie świadczenia, które ze względu na konieczność zapewnienia ich dostępności finansowane są w sposób ustalany odrębnie (art. 136 ust. 2 pkt. 2), jednakże

39 Ibidem, s. 22. 
o zakresie takich świadczeń rozporządzeniem decyduje minister właściwy do spraw zdrowia ${ }^{40}$.

Ryczałt ustalany jest indywidualnie dla świadczeniodawcy z uwzględnieniem czynników zakreślonych ustawowo, odwołujących się zarówno do uwarunkowań ogólnosystemowych jak i samego świadczeniodawcy. Do tych pierwszych należy w pierwszej kolejności wysokość środków finansowych, które zaplanowano w planie zakupowym świadczeń na finansowanie świadczeń PSZ w formie ryczałtu, a ponadto także dane z zakresu liczby, rodzaju, cen i parametrów jakościowych świadczeń udzielanych i sprawozdanych $\mathrm{w}$ poprzednim okresie rozliczeniowym finansowanych w formie ryczałtu systemu zabezpieczenia. Przy analizie konkretnego świadczeniodawcy ustawodawca określa jako element ważący wzrost lub spadek liczby udzielanych świadczeń w perspektywie poprzednich okresów rozliczeniowych.

Powyższe wytyczne znajdują swoje odzwierciedlenie we wzorach matematycznych określonych przez wydanym na podstawie delegacji rozporządzeniu Ministra Zdrowia z dnia 22 września 2017 r. w sprawie sposobu ustalania ryczałtu systemu podstawowego szpitalnego zabezpieczenia świadczeń opieki zdrowotnej ${ }^{41}$.

Przepisy Ustawy nowelizującej o charakterze przejściowym przewidują także delegację dla ministra właściwego ds. zdrowia do wydania rozporządzenia umożliwiającego ustalenie ryczałtu systemu zabezpieczenia na pierwszy okres rozliczeniowy. Ustawodawca nakazał, by wydając te przepisy minister miał na uwadze zapewnienie dostępności do świadczeń oraz stabilności finansowania systemu zabezpieczenia ${ }^{42}$.

Ustalenie szczegółowych warunków umów o udzielanie świadczeń opieki zdrowotnej w ramach systemu zabezpieczenia pozostawiono Prezesowi NFZ, co jest praktyką zupełnie zrozumiałą i stosowaną $\mathrm{w}$ uśoz powszechnie mając na uwadze konieczność szeregu specjalistycznych, technicznych i formalnych uwarunkowań koniecznych do ujęcia przy ustalaniu takich szczegółów ${ }^{43}$.

\footnotetext{
${ }_{40}$ Por. Rozporządzenie Ministra Zdrowia z dnia 19 czerwca 2017 r. w sprawie określenia wykazu świadczeń opieki zdrowotnej wymagających ustalenia odrębnego sposobu finansowania. (Dz. U. poz. 1225).

${ }_{41}$ Dz. U. z 2017 r., poz. 1783.

${ }^{42}$ Por. Rozporządzenie Ministra Zdrowia z dnia 20 czerwca 2017 r. w sprawie sposobu ustalania ryczałtu systemu podstawowego szpitalnego zabezpieczenia świadczeń opieki zdrowotnej na pierwszy okres rozliczeniowy. (Dz. U. poz. 1242).

${ }_{43}$ Zarządzenie Nr 69/2017/DSOZ Prezesa Narodowego Funduszu Zdrowia z dnia 10 sierpnia 2017 r. w sprawie szczegółowych warunków umów w systemie podstawowego szpitalnego zabezpieczenia świadczeń opieki zdrowotnej. (NFZ z 2017 r. poz. 69 z późn. zm.).
} 
Znamiennym dla nowych zasad finansowania jest sposób kwalifikacji świadczeniodawców do systemu zabezpieczenia, której dokonuje dyrektor oddziału wojewódzkiego NFZ - zostało to wpisane wprost do jego zadań w art. 107 ust. 5 pkt 25 uśoz - poprzez sporządzenie i ogłoszenie w Biuletynie Informacji Publicznej NFZ wykazu świadczeniodawców, który określa przynależność do poszczególnego poziomu systemu zabezpieczenia oraz profile tego systemu w ramach województwa na okres 4 lat.

Rola dyrektora oddziału wojewódzkiego jest znacząca w procesie tworzenia PSZ. Należy bowiem wskazać, że już z chwilą sporządzania pierwszego wykazu może on, na podstawie art. 6 Ustawy nowelizującej i po uzyskaniu pozytywnej opinii ministra właściwego do spraw zdrowia, zakwalifikować świadczeniodawcę, które nie spełnia warunków ustawowych wymagań, do każdego z poziomów systemu zabezpieczenia (poza poziomem szpitali ogólnopolskich), o ile podyktowane jest to koniecznością zapewnienia właściwego dostępu do świadczeń opieki zdrowotnej. Ustawodawca nie precyzuje tej przesłanki.

Świadczeniodawca, który nie został zakwalifikowany w wykazie, został zakwalifikowany błędnie lub w stosunku do którego niewłaściwie wskazano profile systemu zabezpieczenia może skorzystać z drogi odwoławczej poprzez złożenie do dyrektora wojewódzkiego oddziału funduszu protestu. Od decyzji rozpatrującej protest przysługuje świadczeniodawcy odwołanie do Prezesa NFZ.

Wykaz jest sporządzany na cztery lata.

Należy podkreślić, że o ile art. 95n w ust. 7 i w ust. 9 przewidują właśnie „decyzję” jako sposób załatwienia sprawy, o tyle art. 16 wyraźnie wyłącza stosowania przepisów Kodeksu postępowania administracyjnego tak do trybu publikowania wykazu, jak i do trybu postępowań odwoławczych. Brak zastosowania reżimu Kodeksu postępowania administracyjnego został dostrzeżony i odbił się dość szerokim echem już na etapie konsultacji publicznych projektu.

Wdrożony Ustawą nowelizującą PSZ kontrastuje zatem z dotychczasowym, opisanym $\mathrm{w}$ niniejszym artykule postępowaniem $\mathrm{w}$ sprawie zawarcia umów ze świadczeniodawcami. Należy przede wszystkim zwrócić uwagę, że publikacja wykazu jako czynności materialno-technicznej jaką jest obwieszczenie pozbawia świadczeniodawców możliwości skutecznego skarżenia rozstrzygnięcia. Stanowi ono jednak sui generis etap wstępny postępowania, w następstwie którego dopiero możliwe jest zawarcie umowy o udzielanie świadczeń zdrowotnych w ramach profili systemu zabezpieczenia - i to jedynie na wniosek dyrektora oddziału 
wojewódzkiego NFZ. Wyłączono wprost stosowanie przepisów o zawieraniu umów w następstwie trybu konkursowego i rokowań. Ustawodawca zakłada, że sama czynność kwalifikująca nie niesie w sobie charakteru uznaniowości z uwagi na ścisłe zasady kwalifikacyjne i w związku $\mathrm{z}$ tym jest to $\mathrm{w}$ istocie czynność materialno-techniczna ${ }^{44}$.

W następstwie omawianych wyłączeń procedury administracyjnej uwypukla się centralizm decyzyjny, świadczeniodawcy przysługuje bowiem jedynie protest od ogłoszonej kwalifikacji do dyrektora oddziału wojewódzkiego i, przy odmowie uwzględnienia, odwołanie do Prezesa Funduszu. To kolejne, po wspomnianej możliwości zakwalifikowania świadczeniodawcy niespełniającego kryteriów do danego poziomu systemu zabezpieczenia, uprawnienie przypisane dyrektorom wojewódzkim Funduszu.

Należy zwrócić uwagę także na równość podmiotów publicznych i niepublicznych, na które wpływ ma utworzenie PSZ. Kryteria kwalifikacyjne (np. wymóg udzielania świadczeń zdrowotnych w ramach szpitalnego oddziału ratunkowego albo izby przyjęć dla szpitali z poziomów I-III i szpitali pediatrycznych) zdają się preferować kompleksowe, najczęściej publiczne podmioty. Zmienia to dotychczasowe postrzeganie konkurencyjności pomiędzy jednostkami publicznymi a niepublicznymi, ograniczając jednocześnie zjawisko fragmentarycznego ubiegania się o najbardziej dochodowe kontrakty przez placówki niepubliczne i „rozmycia” systemowego poziomów opieki szpitalnej i specjalistycznej ${ }^{45}$.

Na marginesie, nie umniejszając jednak wadze tej kwestii, podnieść należy wpływ przyznawanego ryczałtu na jakość i ilość świadczonych usług. Ryczałt systemu zabezpieczenia na pierwszy okres rozliczeniowy bazuje na danych o świadczeniach opieki zdrowotnej udzielonych i sprawozdanych przez świadczeniodawcę za rok 2015, a zatem zakontraktowanych w oparciu przepisy i mechanizmy zniesione przez Ustawę nowelizującą względem PSZ (art. 5 ust. 1 Ustawy nowelizującej). Dopiero zatem kolejny rok pozwoli zweryfikować jak wynikające z uśoz i zawarte w aktach wykonawczych współczynniki wpłyną w praktyce zwłaszcza na ilość, ale także jakość udzielanych przez świadczeniodawców świadczeń.

Poza powyższym na znaczącą odrębność PSZ wobec dotychczasowych trybów zawierania umów ze świadczeniodawcami, a nawet o pewnym wyodrębnieniu sieci szpitali z całości dotychczasowo funkcjonującego schematu świadczyć może

${ }_{44}$ Raport $z$ konsultacji publicznych i opiniowania - tabela, http://legislacja.rcl.gov.pl/docs//2/12290 303/12380817/12380820/dokument270530.doc, dostęp: 25.10.2017 r.

${ }^{45}$ Por. Projekt z dnia 26.09.2017 wraz z uzasadnieniem i oceną skutków regulacji, op. cit., s. 7. 
systemowe umiejscowienie działu IVB. Znajduje się on za działem IVA ustanawiającym regionalną mapę potrzeb zdrowotnych (ustalaną przez wojewodę w porozumieniu z Wojewódzką Radą ds. Potrzeb Zdrowotnych), zaś nie tylko przed działem VI, ale także przed działem $\mathrm{V}$ uśoz zawierającym regulacje dotyczące Narodowego Funduszu Zdrowia.

Powyższe odrębności i różnice, a także nasuwające się w ich wyniku pytania znalazły szeroki oddźwięk w konsultacjach społecznych ustawy. Głos zabierały zarówno środowiska naukowe ${ }^{46}$, lecznicze podmioty publiczne ${ }^{47}$ i niepubliczne ${ }^{48}$, samorządy zawodowe ${ }^{49}$, organizacje związkowe ${ }^{50}$, a także organizacje reprezentujące środowiska biznesowe ${ }^{51}$, w tym zrzeszające pracodawców ${ }^{52}$, oraz organizacje pozarządowe ${ }^{53}$.

Wprowadzony system podstawowego szpitalnego zabezpieczenia świadczeń opieki zdrowotnej istotnie zmienia zatem dotychczasowe zasady dystrybucji środków publicznych przeznaczonych na finansowanie opieki zdrowotnej w Polsce.

${ }^{46}$ Por. http://legislacja.rcl.gov.pl/docs//2/12290303/12380817/12380820/dokument256863.pdf, dostęp: 25.10.2017 r.

${ }_{47}$ Por. Dotyczy: Ustawy o zmianie Ustawy o świadczeniach opieki zdrowotnej finansowanych ze środków publicznych (dot. projekt sieci szpitali), w której zarówno Oddział Gruźlicy i Chorób Płuc oraz Oddział Rehabilitacji nie znajduje swojego miejsca $w$ sieci, https://legislacja.rcl.gov.pl/docs//2/12290 303/12380817/12380820/dokument256914.pdf, dostęp: 25.11.2017 r.

48 Por. Dotyczy: uwag do projektu ustawy o zmianie ustawy o świadczeniach opieki zdrowotnej finansowanych ze środków publicznych, nr w wykazie prac Rady Ministrów: UD116, http://legislacja.rcl.gov. pl/docs//2/12290303/12380817/12380820/dokument256849.pdf, dostęp: 25.10.2017 r.; http://legislacja.rcl.gov.pl/docs//2/12290303/12380817/12380820/dokument256875.pdf, dostęp: 25.10.2017 r.; Uwagi ogólne do projektu ustawy z dnia 26 września 2016 r. o zmianie ustawy o świadczeniach opieki zdrowotnej finansowanej ze środków publicznych, http://legislacja.rcl.gov.pl/docs//2/12290303/1238 0817/12380820/dokument256856.pdf, dostęp: 25.10.2017 r.

${ }_{49}$ Por. Stanowisko nr 15/16/VII Naczelnej Rady Lekarskiej $z$ dnia 4 listopada 2016 r. w sprawie projektu ustawy o zmianie ustawy o świadczeniach opieki zdrowotnej finansowanych ze środków publicznych oraz projektu rozporządzenia Ministra Zdrowia w sprawie określenia profili charakteryzujacych poziomy systemu zabezpieczenia oraz kryteriów kwalifikacji świadczeniodawców do tych poziomów, http://legislacja.rcl.gov.pl/docs//2/12290303/12380817/12380820/dokument256881.pdf, dostęp: 25.10.2017 r.

${ }_{50}$ Por. Dot. konsultacji projektu ustawy o zmianie ustawy o świadczeniach opieki zdrowotnej finansowanych ze środków publicznych, http://legislacja.rcl.gov.pl/docs//2/12290303/12380817/12380820/ dokument256884.pdf, dostęp: 25.10.2017 r.

${ }^{51}$ Por. Stanowisko Konfederacji Lewiatan wobec projektu ustawy o zmianie ustawy o świadczeniach opieki zdrowotnej finansowanych ze środków publicznych, http://legislacja.rcl.gov.pl/docs//2/122903 03/12380817/12380820/dokument256862.pdf, dostęp: 25.10.2017.

52 Por. Stanowisko Pracodawców Rzeczypospolitej Polskiej wobec projektu ustawy o zmianie ustawy o świadczeniach opieki zdrowotnej finansowanych ze środków publicznych, http://legislacja.rcl.gov.pl/ docs//2/12290303/12380817/12380820/dokument256899.pdf, dostęp: 25.10.2017 r.

53 Por. http://legislacja.rcl.gov.pl/docs//2/12290303/12380817/12380820/dokument256852.pdf, dostęp: 25.10.2017 r. 
Pozostając w ramach zasad konstytucyjnych i umiejscawiając systemowo zmianę $\mathrm{w}$ uśoz ustawodawca istotnie przekształca jednak system opieki zdrowotnej finansowany ze środków publicznych w Polsce podążając jak się zdaje za tymi poglądami doktryny, które w leczeniu, w tym w leczeniu szpitalnym widzą obszar, który powinien być w sposób szczególny „chroniony” przez państwo przed wpływem mechanizmów rynkowych ${ }^{54}$.

Tendencje te zaakcentował już wcześniej Minister Zdrowia w przedstawionej w lipcu ubiegłego roku ${ }^{55}$ strategii zmian mającej na celu wprowadzenie Narodowej Służby Zdrowia. Zakłada ona, poza wprowadzeniem sieci szpitali, cały szereg zmian na czele z likwidacją Narodowego Funduszu Zdrowia, przekazaniem kompetencji NFZ do Ministerstwa Zdrowia, powołaniem Wojewódzkich Urzędów Zdrowia w miejsce dotychczasowych oddziałów wojewódzkich i co najważniejsze przemodelowanie całości systemu w ten sposób, by z obecnego systemu ubezpieczeniowego przejść na system budżetowej służby zdrowia ${ }^{56}$. Zgodnie z propozycjami strategii Minister Zdrowia będzie dysponentem Państwowego Funduszu Celowego „Zdrowie”, finansowego z określonej części wpływów PIT i dotacji $\mathrm{z}$ budżetu państwa. Jak podnosi się w opisie strategii, dotychczasowe rozwiązania oparte na mechanizmach komercyjnych i konkurencji niosą ze sobą szereg elementów negatywnych dla systemu i pacjenta ${ }^{57}$.

Uwidacznia się zatem poprzez ustawę nowelizującą i regulacje dotyczące PSZ, że mimo umiejscowienia zmian systemowo w uśoz jako ustawie stanowiącej, wespół z ustawą o działalności leczniczej ${ }^{58}$, swego rodzaju fundament obowiązującego systemu składkowego, to są te zmiany w istocie przygotowane już pod założenia zmienionego systemu finansowania i w konsekwencji organizacji ochrony zdrowia: dotyczą szerokiego wycinka systemu ochrony zdrowia, dokonują integracji z leczeniem szpitalnym ambulatoryjnej opieki specjalistycznej, a nawet

54 S. Morris, N. Devlin, D. Parkin, Ekonomia w ochronie zdrowia, Warszawa 2012, s. 26-27.

${ }_{55}$ Narodowa Stużba Zdrowia - minister Konstanty Radziwiłt przedstawił założenia reformy, http:// www.mz.gov.pl/aktualnosci/narodowa-sluzba-zdrowia-minister-konstanty-radziwill-przedstawil-zalozenia-reformy/, dostęp: 25.10.2017.

${ }^{56}$ O cechach obu systemów w państwach europejskich zob. szerzej A. Hnatyszyn-Dzikowska, B. Łyszczak Rola sektora prywatnego w finansowania europejskich systemów ochrony zrowia [w:] K. Ryć, Z. Skrzypczak (red.), Ochrona zdrowia i gospodarka. Sposoby finansowania, Warszawa 2010, s.30.

${ }^{57}$ Narodowa Stużba Zdrowia. Strategia zmian w systemie ochrony zdrowia w Polsce, http:// www.mz.gov.pl/wp-content/uploads/2016/07/narodowa-sluzba-zdrowia-bez-dat.pdf, dostęp: 25.10.2017 r.

${ }^{58}$ Ustawa z dnia 15 kwietnia 2011 r. o działalności leczniczej. (t.j. Dz. U. z 2016 r. poz. 1638 z późn. zm.). 
nocnej i świątecznej opieki lekarskiej, wprowadzają kryteria kwalifikacyjne możliwe w praktyce do spełnienia głównie przez szpitale publiczne i odchodzą niemal całkowicie w obszarze opieki szpitalnej od kontraktowego systemu zakładającego konkurencję świadczeniodawców oraz rozliczanie świadczeń w oparciu o wykonanie kontraktu rozumianego jako iloczyn liczby wykonanych świadczeń i stawki za poszczególne świadczenie.

Jednocześnie znowelizowane i wprowadzone Ustawą nowelizującą przepisy przyznają szerokie kompetencje stanowiące $\mathrm{w}$ drodze delegacji do wydawania rozporządzeń zarówno ministrowi właściwemu do spraw zdrowia (zwłaszcza w zakresie dookreślenia kryteriów kwalifikacyjnych) jak i Prezesowi NFZ, a także niezwykle silnie akcentują pozycję dyrektora oddziału wojewódzkiego NFZ, który mimo założonych kryteriów kwalifikacyjnych ma niemalże nieograniczone pole manewru w zakresie kwalifikowania podmiotów niespełniających określonych kryteriów do poszczególnych poziomów systemu zabezpieczenia. Ponadto sam proces kwalifikowania, w drodze wykazu obwieszczanego jedynie w BIP, wyłączony jest spod kontroli odwoławczej w reżimie przepisów postępowania administracyjnego.

Zdają się być to zatem rozwiązania przygotowywane już pod nowych aktorów systemu ochrony zdrowia - Ministra Zdrowia jako organizatora i zarazem także płatnika w systemie oraz dyrektorów wojewódzkich urzędów zdrowia jako jego przedstawicieli, organizujących $\mathrm{w}$ imieniu państwa zabezpieczenie świadczeń zdrowotnych finansowanych ze środków publicznych na terenie województw.

Sam system finansowania i kwalifikacji w ramach PSZ ma jak się wydaje za zadanie już na obecnym etapie poprzez per se mechanizmy finansowe (dobór kryteriów) wykluczyć świadczeniodawców niepublicznych albo takich, którzy nie świadczą kompleksowo usług szpitalnych. W środowisku świadczeniodawców można spotkać także głosy, że również w innych obszarach, jak na przykład ambulatoryjnej opieki specjalistycznej, wprowadzane będą wymogi w istocie faworyzujące szpitale jako miejsca udzielania świadczeń.

Prawo kształtuje w dużej mierze ekonomikę w ochronie zdrowia, a problem sposobu gromadzenia i wydatkowania środków publicznych (i nie tylko) celem zapewnienia zabezpieczenia zdrowotnego obywateli, stanowi istotny problem dla większości państw ${ }^{59}$. Proponowane rozwiązania będzie można ocenić dopiero po

${ }^{59}$ J. Leowski, op. cit, s. 91 
upływie czasu, jednakże wpisują się one w długą historię sporu pomiędzy zwolennikami modelu składkowego i modelu budżetowego ${ }^{60}$.

Czy model ryczałtowy zapewni właściwy rachunek kosztów? Jak przełoży się na jakość świadczonych usług i efektywność systemu? I wreszcie czy stanowi zwiastun rychłej reorganizacji sfery finansów publicznych w obszarze związanym z ochroną zdrowia? Nie jest on bowiem rozwiązaniem jawiącym się jako przewidziane do harmonijnej współpracy $\mathrm{z}$ dotychczas obowiązującym systemem ubezpieczeniowym.

\section{Bibliografia}

Białynicki-Birula P., Zmiany $w$ systemie finansowania ochrony zdrowia $w$ Polsce. Perspektywa międzynarodowa, Kraków 2006

Dercz M. (red.), Prawo publiczne ochrony zdrowia, Warszawa 2013

Fiutak A., Prawo $w$ medycynie, Warszawa 2010

Leowski J., Polityka zdrowotna a zdrowie publiczne. Ochrona zdrowia w gospodarce rynkowej, Warszawa 2004

Morris S., Devlin N., Parkin D., Ekonomia w ochronie zdrowia, Warszawa 2012

Nojszewska E. (red.), System ochrony zdrowia. Problemy i możliwości ich rozwiązań, Warszawa 2011

Nojszewska E., Malinowski W., Sikorski S., Komercyjne świadczenie usług medycznych przez szpitale. publiczne, Warszawa 2017

Pacian J. (red.), Prawna ochrona zdrowia pacjenta, Warszawa 2017

Pietraszewska-Macheta A., Kontraktowanie świadczeń przez Narodowy Fundusz Zdrowia. Przepisy, praktyka i orzecznictwo, Warszawa 201

Ryć K., Skrzypczak Z. (red.), Ochrona zdrowia i gospodarka. Sposoby finansowania, Warszawa 2010

\section{Akty prawne}

Konstytucja Rzeczypospolitej Polskiej z dnia 2 kwietnia 1997 r. (Dz. U. Nr 78, poz. 483 z późn. zm.).

Ustawa z dnia 27 sierpnia 2004 r. o świadczeniach opieki zdrowotnej finansowanych ze środków publicznych (t.j. Dz. U. z 2017 r. poz. 1938)

Ustawa z dnia 23 stycznia 2003 r. o powszechnym ubezpieczeniu w Narodowym Funduszu Zdrowia (Dz. U. z 2003 r. Nr 45, poz. 391 z późn. zm.) - nieobowiązująca

Ustawa z dnia 23 marca 2017 r. o zmianie ustawy o świadczeniach opieki zdrowotnej finansowanych ze środków publicznych. (Dz. U. poz. 844)

Ustawa z dnia 27 sierpnia 2009 r. o finansach publicznych (t.j. Dz. U. z 2017 r. poz. 2077).

60 Szerzej zob. ibidem, s. 105-164 
Ustawa z dnia 14 czerwca 1960 r. Kodeks postępowania administracyjnego (t.j. Dz. U. z 2017 r., poz. 1257)

Ustawa z dnia 15 kwietnia 2011 r. o działalności leczniczej. (t.j. Dz. U. z 2016 r. poz. 1638 z późn. zm.)

Rozporządzenie Ministra Zdrowia z dnia 11 grudnia 2014 r. w sprawie nadania statutu Narodowemu Funduszowi Zdrowia. (Dz. U. poz. 1840)

Rozporządzenie Ministra Zdrowia z dnia 19 czerwca 2017 r. w sprawie określenia wykazu świadczeń opieki zdrowotnej wymagających ustalenia odrębnego sposobu finansowania. (Dz. U. poz. 1225).

Rozporządzenie Ministra Zdrowia z dnia 22 września 2017 r. w sprawie sposobu ustalania ryczałtu systemu podstawowego szpitalnego zabezpieczenia świadczeń opieki zdrowotnej (Dz. U. z 2017 r., poz. 1783)

Rozporządzenie Ministra Zdrowia z dnia 20 czerwca 2017 r. w sprawie sposobu ustalania ryczałtu systemu podstawowego szpitalnego zabezpieczenia świadczeń opieki zdrowotnej na pierwszy okres rozliczeniowy. (Dz. U. poz. 1242)

Zarządzenie Nr 69/2017/DSOZ Prezesa Narodowego Funduszu Zdrowia z dnia 10 sierpnia 2017 r. w sprawie szczegółowych warunków umów w systemie podstawowego szpitalnego zabezpieczenia świadczeń opieki zdrowotnej. (NFZ z 2017 r. poz. 69 z późn. zm.)

\section{Orzecznictwo}

Wyrok Trybunału Konstytucyjnego z dnia 7 stycznia 2004 r., sygn. K 14/03, Dz. U. Nr 5, poz. 37

\section{Wykaz skrótów}

Uśoz - Ustawa z dnia 27 sierpnia 2004 r. o świadczeniach opieki zdrowotnej finansowanych ze środków publicznych (t.j. Dz. U. z 2017 r. poz. 1938)

Uofp - Ustawa z dnia 27 sierpnia 2009 r. o finansach publicznych. (t.j. Dz. U. z 2017 r. poz. 2077)

NFZ - Narodowy Fundusz Zdrowia

PSZ - system podstawowego szpitalnego zabezpieczenia świadczeń opieki zdrowotnej

BIP - Biuletyn Informacji Publicznej 